\begin{tabular}{l}
$\begin{array}{l}\text { Journal of Economics and Behavioral Studies (ISSN: 2220-6140) } \\
\text { Vol. 9, No. 5, pp. 219-229, October } 2017\end{array}$ \\
\hline \hline
\end{tabular}

\title{
Understanding the Theory of Consumption in the Context of a Developing Economy
}

\author{
David Mautin Oke*, Koye Gerry Bokana \\ College of Law and Management Studies, University of KwaZulu-Natal, South Africa \\ okdam76@yahoo.com*, bokanakg@ukzn.ac.za
}

\begin{abstract}
This paper synthesizes the theory of consumption using some Nigerian contexts. The argument on what determines consumption is yet an unfinished task. We tested the general consumption function using Nigerian data covering 1981-2012. Based on the diagnostics, we employed a vector autoregression-in-first difference approach. The result shows that previous incomes (up to two lags) may not be significant in influencing consumption in Nigeria but previous consumption levels (up to two lags) attained may do. In addition, consumers in Nigeria may reduce their consumption in the current year based on their knowledge of previous year consumption but may raise the current consumption level due to their experience of last two years consumption. This corroborates suggestions that macro-econometricians must analyze consumption beyond the general consumption function. The pattern of historical data also suggests that consumption may be difficult to predict in Nigeria. Therefore, government of Nigeria may succeed in influencing its aggregate demand which consumption is the major component if its income and tax policies are permanent, rather than being temporary.
\end{abstract}

Keywords: Consumption, Vector autoregression-in-first difference, Nigeria

\section{Introduction}

Virtually everyone makes use of goods and services, that is, consumes them to derive satisfaction or utility or pleasure or happiness from them. Consumption is therefore a necessary concept in nature as well as economics. Economics itself is as old as nature, although was not formally recognized early until the $13^{\text {th }}$ to $14^{\text {th }}$ century. Consumption as a concept goes together with saving (see Blanchard and Fischer, 1989; Parker, 2010; Romer, 2011). This is why in macroeconomics, the theory of consumption and saving are most often simultaneously treated. In technical terms, the part of income that people do not save is the consumer expenditure. Clearly, consumer expenditure connotes the amount of money, say naira and kobo expended on commodities. The generic word for good and service is commodity. While a good is tradable and tangible, service is non-tradable and intangible. For instance, if David who lives in Nigeria wants to consume a haircut service of a firm based in the United Kingdom, he has to obtain a visa to travel to the United Kingdom for that purpose. This is not the case if the good is tradable. However, there are certain services that do not require physical travelling such as receiving a lecture from any part of the world on an electronic platform. The difference between consumption and consumer expenditure is that while the former is associated with utility derivation, the latter is the expenditure made (see Chamberlin and Yueh, 2006).

An interesting question in macroeconomics is- who actually consumes? Is it the individual persons such as Ada, Tayo and Lawan or the firms such as Dangote Floor Mill, Lola Bakery and Uche Shoes Making Limited or the governments such as Keffi Local Government, Lagos State Government and Federal Government of Nigeria? The answer to this question is that, although government also consumes but consumption is the individual persons' consumptions. This is why consumption when referred to means private consumption. Expenditures on assets or capital goods by firms are what economists refer to as investment or private investment while expenditures made by governments whether local, state or federal are called government expenditure or public spending or public expenditure or government purchases. Government expenditure comprises capital expenditure, otherwise called government investment and recurrent expenditure also known as government consumption. The addition of expenses made on commodities by all the persons residing in an economy makes up consumer expenditure or consumption. This means that consumer expenditure or consumption is a macroeconomic concept.

Consumer expenditure can be broken down into expenditures made on durable goods, non-durable goods and service. Durable goods are by nature or fabrication not used up in the process of consumption while in the case of non-durable goods; they are used up when consumed. Therefore, durable goods stand the test of time but non-durable goods do not last. Service shares the same features with non-durable goods. Service is 
instantly used up in consumption process. Examples of non-durable goods are fresh tomatoes, bread, pepper and injection needle while examples of durable goods are eye glasses, laptop, television set, house furniture, and mattress. Examples of services are teaching, lecturing, coaching, hawking, selling, consulting, auditing and accounting. Consumption is the largest component of aggregate expenditure or aggregate demand (see Chamberlin and Yueh, 2006). After investment, it is the next volatile variable in the aggregate demand function. It occupies a pertinent role in growing an economy. Although, contemporary economists have laid more emphasis on raising investment levels to stimulate economic growth, consumption roles in economic growth has remained significant since 1930s when Maynard Keynes argued for consumption against investment as a needed ingredient for growing an economy (see Keynes, 1936). Without consumption, firms will fold up and investment will dwindle.

Figure 1: Nigeria's Private Consumption (1981-2012)

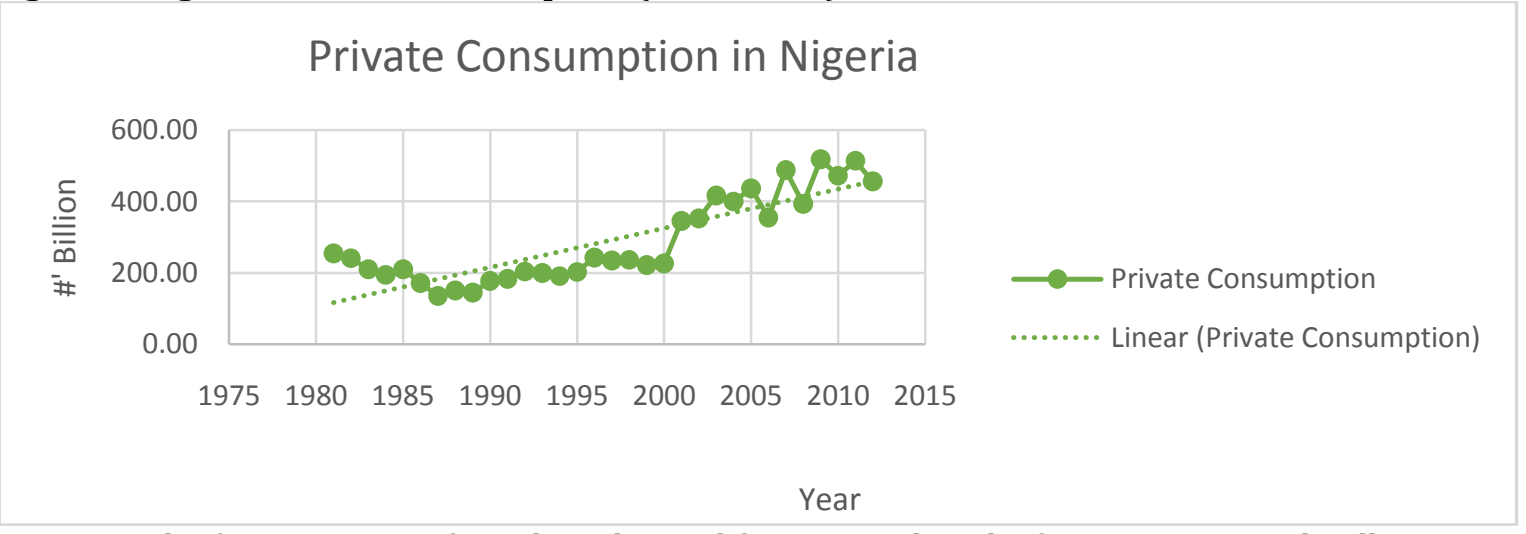

Source: Author's computation from data obtained from Central Bank of Nigeria Statistical Bulletin, 2014

Figure 2: Absorption Share in Gross Domestic Product in Nigeria (1981-2012)

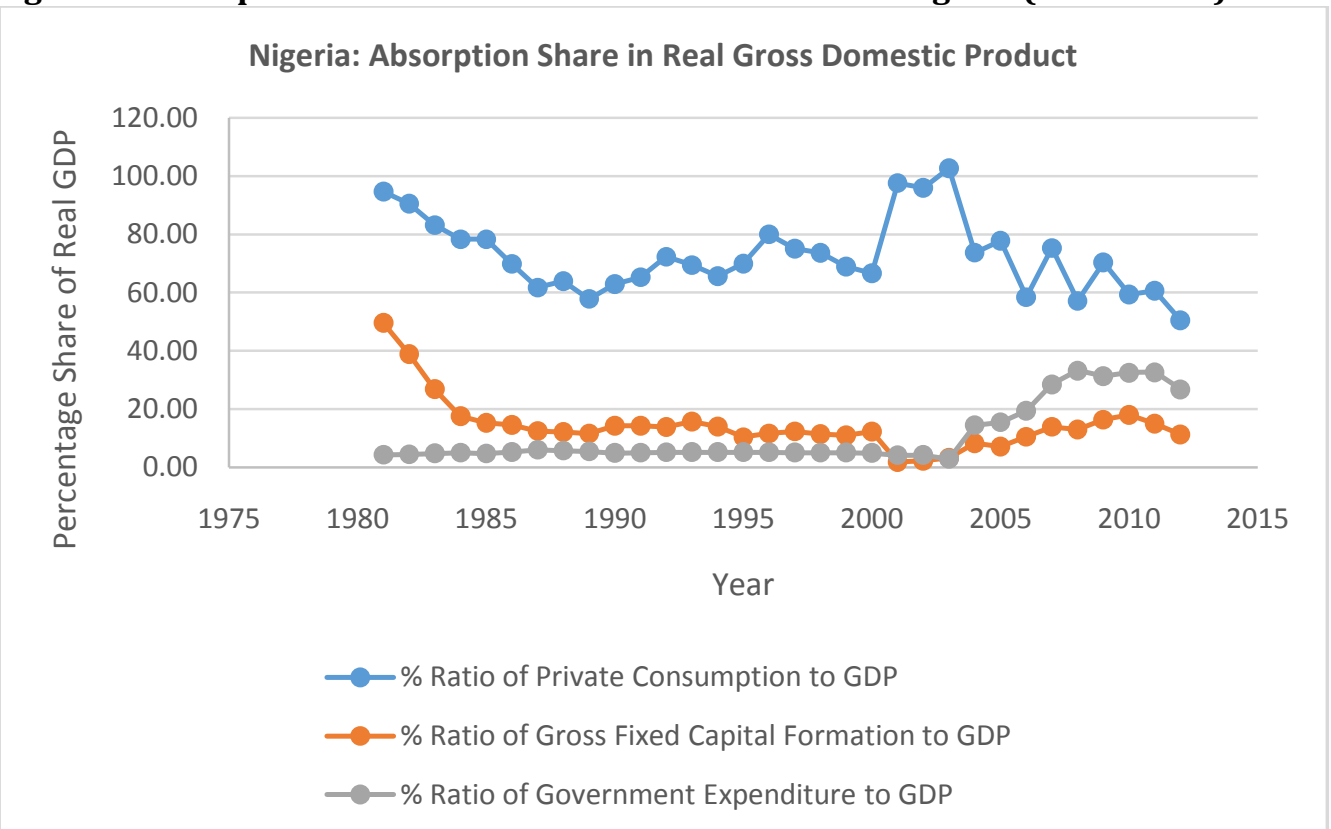

Source: Author's computation from data obtained from Central Bank of Nigeria Statistical Bulletin, 2014

We show the movements of private consumption pattern in Nigeria in figure 1 with a linear curve across it to depict deviations from the overall average consumption in 1981-2012. The graph reveals that consumption levels were above the overall average level in 1981-1985; 2003-2005; 2007 and 2009-2011. Over the reference period, the lowest consumption level in Nigeria was recorded in 1987 while the highest value was 
recorded in 2009. Absorption includes private consumption, investment (represented by gross fixed capital formation) and government expenditure. Figure 2 shows the share of each of the components of absorption in GDP. The figure reveals that private consumption has always been the largest share of Nigeria's GDP with the least been 50.51 percent in 2012 and the highest been 102.77 percent in 2003 over the reference period. However, the behavior of the private consumption-GPP share like the consumption curve in figure 1 has been a form of random walk, hence unpredictable. This supports the random walk hypothesis of consumption propounded by Hall (1978). Depending on the state of the economy, consumption can be enhanced/reduced or influenced by economic policy. An example is when a country is in debt crisis and its output fell due to a long-term shock while the output is also less than absorption, the ideal dose of policy recommendations will be a reduction in consumption to the level the output has fallen and a debt ceiling. In order to increase output, there will be need for right macroeconomic policy such as reduction in interest rate coupled with and accompanied by institutional and structural policies.

The relevance of this study is in three folds. First, it simplifies the theory of consumption using the Nigerian context to aid understanding of the concept to Nigerian readers. Second, readers from any part of the world can understand at a glance, the developments in theories of consumption overtime, given an up-to-date discussion provided in a synopsis format. Finally, it unravels the methodological challenges in analyzing consumption theory. We divide the study into five sections. Following this introduction is a theoretical and methodological review on consumption in section two. In the third part, we present the methodology while the discussion of the findings comes up in the fourth section. The final part gives the concluding remarks.

\section{Literature Review}

Revising the Theoretical and Methodological Issues in Consumption: Stylized Facts: The theory of consumption started with the work of Maynard Keynes in 1936 when he propounded the Absolute Income Hypothesis (AIH) or otherwise called the Keynesian consumption theory. He used intuition to submit that current disposable income is what determines current consumption. As at that time, the knowledge of econometrics has not become profound. He was the first to come up with marginal propensity to consume (MPC) and average propensity to consume (APC) in attempt to describe the relationship between aggregate consumption and current disposable income. Marginal propensity to consume is the change in consumption due to an extra change in disposable income while average propensity to consume is the ratio of consumption to disposable income. In equation (1), as put forward by Keynes, $C_{t}$ is current consumption; a is autonomous consumption; $\mathrm{b}$ is the marginal propensity to consume and $\mathrm{Y}_{\mathrm{t}}$ represents current disposable income.

$C_{t}=a+b Y_{t}$

There are three features of the Keynes' postulate on consumption. First, the marginal propensity to consume is between zero and one. Second, the average propensity to consume falls as income increases and lastly the major driver of consumption is income and not interest rate contrary the argument by the Classical School. Empirical works on consumption using short time-series households' data were in support of Keynes' proposition (Chamberlin and Yueh, 2006). However, studies that used long time-series did not show a falling APC as income increases (Chamberlin and Yueh, 2006). The paradox of Kuznets (1942)is on empirical anomaly between the comparativemagnitude of MPC and APC. He said changes in APC depends on the value of the autonomous consumption. When the autonomous consumption is zero, people spend an equal share of their increase income, hence MPC = APC. This happens in the long run. However, in the short-run, the autonomous consumption is greater than zero, thus people spend less share of the increase in their income. In this short-run, MPC < APC. While there is a proportinal relationship between disposable income and consumption in long-run, there is non-proportional relationship between the two variables in the short-run.

A study by James Tobin revealed that increases in asset properties owned, aftermath-war urbanization, diversities of new consumer goods after war and increasing proportion of the aged in the entire population have shifted the short-run consumption function upwardly in a slowly manner thereby showing a scenario where MPC is less than APC in the short-run but because the upward shift in consumption returns to the longrun consumption, MPC will be equal to APC in the long-run (see Parker, 2010). Another consumption hypothesis is the Relative Income Hypothesis (RIP). This was described in the work of James Duesenberry 
(1949). The time series version of this theory shows that individual consumption depends on his past highest income while the cross-section version saays thatindividual consumption is dependent on the consumption pattern of the Jonesses in ones group. The time series version leads to a ratchet effect where individual consumption does not fall significantly when income falls because consumers would like to maintain an initial consumption level attained during a high income period by reducing their savings. Both the Absolute Income Hypothesis and the Relative Income Hypothesis have become outdated in modern macroeconomics. Although the two hypotheses were of relevance in the 1950s and 1960s, they failed to address the problem of consumption smoothing by not considering intemporary choice of the consumer in weighing his consumption and saving choices from the present and future income conditions. In particular, the RIP has methodological problem which has to do withchallenges in modeling interdependent utility.

Contemporary research on consumption are predicated largely on the Irving Fisher's consumption model. It says that in order to achieve a high level of utility, the consumer is faced with an intertemporal choice where he chooses to consume more today and save less thereby having to reduce consumption in the future if he does not borrow or consume less today and save more thereby increasing his consumption in the future. Where he borrows, he pays interest rate. So, the amount he borrows in the future so as to consume will depend on the rate of interest. When he saves today, he also earns interest rate. If we assume borrowing (or lending) interest rate and saving interest rate to be the same (that is, zero interest rate spread), his current income has more value than his future income because he earns interest on it if he saves today and his present consumption is more expensive than future consumption because of the interest rate charged on borrowing for consumption purpose in the future or because his future consumption is based on income saved, which yielded interest. The consumer has an intertemporal budget contraint which describes his lifetime income or resources that can be expended on current and future consumptions (see Fisher, 1930 and Chamberlin and Yueh, 2006).

Franco Modigliani and his co-researchers namely Albert Ando and Richard Brumberg propounded the Life Cycle Hypothesis (LCH) in the mid-1950s (see Parker, 2010). Their work showed that consumption is determined by income, represented by $\mathrm{Y}$ and wealth designated by $\mathrm{W}$ in equation (2). Notice that $\mathrm{a}$ and $\mathrm{b}$ are arbitrary consumption coefficients.

$C=a W+b Y$

Income is said to vary in a way that can be predicted over somebody's lifetime. Consumption smoothing over someone's lifetime is done by borrowing and saving. In 1957, Milton Friedman gave the Permanent Income Hypothesis (PIH). This says that individual persons experience both transitory and permanent changes in their incomes. They can borrow or save to smooth their consumptions whether expected or not.

$C=C^{P}+C^{\mathrm{T}}$

$Y=Y^{P}+Y^{T}$

Permanent income $\left(\mathrm{Y}^{\mathrm{P}}\right)$ is the expected income while permanent consumption $\left(\mathrm{C}^{\mathrm{P}}\right)$ is the planned consumption as well as a constant proportion of the permanent income. The income that is not expected is transitory $\left(\mathrm{Y}^{\mathrm{T}}\right)$ while consumption that someone does not plan for is transitory $\left(\mathrm{C}^{\mathrm{T}}\right)$. There is no relationship between transitory and permanent consumption as well as between transitory and permanent income. The association between transitory consumption and transitory income is also zero. What determines consumption, according to this hypothsis is permanent income. The LCH and the PIH assumed that households live finitely and infinitely, respectively. The Diamond Overlapping-Generations (OGs) and Ramsey Cass Koopmans (RCK) models of growth built their consumption models taking a clue from the LCH and PIH, respectively (see Diamond, 1965; Weil, 2008 and Romer, 2011). However, the RCK model has both finite and infinite horizons analysis (see Romer, 2011).

Besides, Robert Hall came up with the Random-Walk Hypothesisin 1978. He said that fluctuations in consumption over time cannot be predicted if the Permanent Income Hypothesis is true and given the assumption of rational expectations about future income. Mainwhile, David Laibson in his Pull of Instant Gratifification Hypothesis in 1997, submitted that people end up saving less than they desire because of their option for more consumption today so as to satisfy their immediate want. This hypothesis has argued 
that psychology effect is also critical in analyzing what determines consumption (see Laibson, 1997 and Chamberlin and Yueh, 2006). Laibson had continued to work on his hypothesis in 2000, 2004, 2011 and the latest edition published in 2013 in conjunction with Christopher Harris (see Harris and Laibson, 2013). This edition was coined as the "instantaneous gratification model" which works with general utility functions under both perfect and imperfect markets. Besides, government can use the model to make linear and nonlinear rules in the long-run. Another interesting thing about the model is that it also yields a unique equilibrium even under the assumption that the households live endlessly. As a result, a range of problems relating to models that are dynamically unpredictable or inconsistent are solved. This model, apart from giving one yardstick of analysing welfare, it also reinstates the initial submission that people tend to behave in a way that they overconsume.

Arising from the theories of consumption, there are many consumption drivers. A number of the factors include current disposable income; interest rate; future income; wealth or total assets; urbanization drive; rational expectation of the consumer; permanent income and proportion of the aged people in the total population; retirees and unemployed persons in the population. Others include proportion of the employed persons in the population; varieties of new consumer goods and services; past peak income; consumption pattern of friends, colleagues, associates or other persons known or encountered or seen; uncertainty, precautionary saving, financial market constraints, financial market deregulation and psychological factors. On the empirical scene, some of the variables that have been used include total wealth, financial wealth, real interest rate, housing wealth, nominal interest rate, inflation-adjusted income, relative price of non-durables/ durables, withdrawal, mortgage equity, long-term interest rates and demographic factors. Building expectations into the consumption model have included exchange rate (by forward looking or learning approach), wages, prices, stock prices, adaptive or implicit approaches.

Modeling the multivariate consumption function is problematic and an issue of ideology based on econometric knowledge. Private consumption and disposable income as highlighted in Keynes' analysis is a settled matter. However, several empirics have shown that consumption is not largely dependent on disposable income. As earlier enunciated, the RIP's argument of influence of consumption pattern of people in ones group has also been set aside or outdated. Arising from PIH, salaries and wages, contributed pension and gratuity, and profits are some examples of permanent incomes while bonuses, bursaries, gifts and grants are transitory incomes. Permanent consumption is the normal consumption expenditure. Expenditures such as unexpected car repair expenses, temporary college tuition expenses and unexpected medical bills are transitory consumption. In econometric modeling, permanent income can be defined as the magnitude of a fixed yearly income flow that would have equal present value as the (probable uneven) anticipated actual income flow (Parker, 2010). Therefore, to compute permanent income from a budget constraint, there must be a known future income path. Early researchers, with the aid of adaptive expectations model assumed that permanent income is obtainable from a function of current and past incomes that is both linear and stable (see Parker, 2010). The flaw of this technique that renders it undependable has to do with differentiating between known permanent and temporary incomes. The stochastic or disturbance term in a regression of consumption can be recognized as transitory consumption (Parker, 2010). Permanent income can also be expressed as wealth multiplied by real rate of interest (Parker, 2010).

Measuring expectation is also a problematic econometric issue. There are no definite and reliable data series on the expected values of macroeconomic variables in the future. At best, any expected value is based on probability after taken care of downside and upside risks. The expected variable can be true or untrue or close to truth or far from it. Its falsehood and truthfulness are functions of mastery and luck. Since 1970s, econometricians have moved from deterministic models to stochastic models in order to include rational expectations (Parker, 2010). One mathematical way of analyzing expectation is by developing a linear operator (see Romer, 2011). Since a quadratic consumption function will yield a linear marginal utility, expectation has, therefore been factored into the consumption function. The implication is that the principles of certainty equivalence is observed when quadratic utility functions are used, Certainty equivalence means that the same decision is made with maximizing expected utility that would have involved maximizing actual utility with certainty that the variables will change in a particular way in the future. Quadratic utility functions are prevalent in stochastic models since such models simply go with certainty equivalence (Parker, 2010). However, quadratic utility function is limited because of its bliss point making it an approximate of a 
true utility function. This is because in reality, marginal utility cannot be negative. Quadratic utility functions have parabola shape, which have a peak such that when consumption exceeds the peak value, marginal utility becomes negative. One option in solving this problem is by including bliss consumption in the quadratic utility function.

\section{Methodology}

To sum up the past and contemporary discussions on what make people to consume, current disposable income is often used as an underlying factor in consumption analysis. This enables economists to draw a twoquadrant graph of consumption-disposable income relationship while holding other consumption drivers constant. Therefore, drawing from the work of Keynes (1936) on consumption, most often, economists state consumption function in contemporary fashion as:

$$
C=C_{0}+C_{1} Y_{d} \ldots \ldots \ldots . . .(5) \quad\left[C_{0}>0 ; 0 \leq \mathrm{C}_{1} \leq 1\right]
$$

Where in equation (1), C represents consumption; $\mathrm{C}_{0}$ stands for consumption intercept otherwise or popularly known as autonomous consumption; $\mathrm{C}_{1}$ is the slope of the consumption function, which is commonly referred to as induced consumption, and $\mathrm{Y}_{\mathrm{d}}$ is the disposable income. The autonomous consumption is the consumption that does not depend on income. It is probably that someone dashed the consumer the money. Simply, he does not earn the income but he consumes. We do not consider a situation where people derive the income from unethical means. Although, the knowledge of ethics or philosophy underpins the genesis of economics as a body of knowledge, economics especially positive economics does not recognize ethics as such in the analysis of economic problems. Nevertheless, unethical activities are part of underground economic activities. In aggregating economic variables like consumption and saving, these activities are not considered.

In Africa, for example, where the underground economy is large, the gross domestic expenditure which private consumption is a component has been said to be under-estimated. This calls for legislations to reduce the size of the underground economy and their full implementations. On the other hand, induced consumption is that consumption that depends on income; hence it is the marginal propensity to consume. Given the fact that individuals must consume even when they do not earn income, the autonomous consumption will always be a positive value, although it has been found in the literature to be zero in the long run. The disposable income earned is shared between saving and consumption; hence the sum of changes in saving and consumption with respect to changes in income is always equal to 1 . Supposing that there is a whole saving of disposable income (a rare or impossible case indeed in a whole economy). Consequently, the marginal propensity to consume (MPC) which is the ratio of change in consumption to change in disposable income will be zero and the marginal propensity to save (MPS) which is the ratio of change in saving to change in disposable income will be 1. The reverse holds for MPC and MPS when we consume all the disposable incomes. This is also a rare case in the whole economy. However, there are occasions where some people consume more than they save. Sometimes people do not even save any amount, they borrow or sell their assets to consume. This is the case of negative saving or dissaving. Economic theories on consumption have explained that whole saving or consumption of disposable income by masses is impossible. Therefore, MPC and MPS must always fall between zero and one.

In equation (5), the autonomous consumption is not zero because we do not assume a long-run situation. The autonomous consumption is a positive value as earlier stated. The induced consumption is between zero and one but most of the time greater than zero but less than one since people must save in the economy. In most developed economies, the induced consumption is high. This is because consumption levels are far ahead of saving. However, the use of $\mathrm{C}_{0}$ and $\mathrm{C}_{1}$ in equation (5) is arbitrary. In order to test the consumption- disposable income model, we employ the real per capita gross national income (RGNI per capita) obtained from the National Bureau of Statistics archives to represent disposable income since there is no distinctive data on Nigeria's disposable income from the Government agencies. Although, there are forecasts on the variable by some individual research bodies but the data seemed unreliable. We believe that RGNI per capita is a close proxy of disposable income since the latter comes from personal income, which is a derivation from GNI. In addition, both RGNI per capita and disposable income are policy-adjusted variables. Disposable income is taxadjusted income (that is, fiscal policy-adjusted income) while RGNI per capita is inflation-adjusted income 
(that is, monetary policy-adjusted income). Data on private consumption is not a problem. We easily obtained it from the Central Bank of Nigeria Bulletin, 2014. The data employed covered the period, 1981-2012.

As an initial econometric step, we used the Dickey-Fuller Generalized Least Square (DF-GLS) approach to depict the nature of the two variables. Examining the stationarity of a variable is considered in a number of ways but the DF-GLS has been noted as one of the cutting-edge methods (see Ng \& Perron, 2001; Elliott et al., 1996). Comparable to the Ng-Perron technique, DF-GLS checks no unit root at either difference stationary or trend stationary. The two shapes of DF-GLS are constant, and constant and linear trend. We state the test equations as:

$$
\begin{aligned}
& \Delta Z_{t}=\eta_{0}+\eta_{1} Z_{t-1}+\sum_{i=1}^{n} \pi_{i} \Delta Z_{t-i}+v_{t} \\
& \Delta Z_{t}=\eta_{0}+\eta_{1} Z_{t-1}+\eta_{1} t+\sum_{i=1}^{n} \pi_{i} \Delta Z_{t-i}+v_{t} \\
& H_{0}: \quad \eta_{1}=0 \quad H_{1}: \quad \eta_{1}<0
\end{aligned}
$$

From equations (6) and (7), $Z_{t}$ stands for the time series variables and $v_{t}$ represents time and residual. Equation (6) is the test model with constant only while equation (7) is for constant and linear trend. Engle \& Granger (1987) gave a cointegration method that comprises two steps for a uni-variate model. The first step is to estimate the long-run equation, which implies the equilibrium equation. We state such an equation for our model in equation (8)

$$
C_{t}=\beta_{0}+\beta_{1} Y_{t}+u_{t}
$$

The notation of $C_{t}$ remains the current consumption; $Y_{t}$ is income; $\beta_{0}$ and $\beta_{1}$ are the consumption intercepts while $u_{t}$ commonly known as the stochastic term represents other omitted variables.

The estimated residuals of the ordinary least squares (OLS) from equation (8), which is $\hat{u_{t}}=C_{t}-\hat{\beta}_{0}-\hat{\beta}_{1} Y_{t}$ are a gauge of disequilibrium. To test for cointegration, the $\boldsymbol{u}_{t}$ is tested for stationarity. If it is stationary or has no unit root, there is cointegration but if it is not stationary, there is no cointegration. Where cointegration exists, an error correction mechanism (ECM), which is the second step of the Engle-Granger procedure, is done. This measures the speed of adjustment towards long-run or extent to which deviation from long-run is corrected in the short-run.

In a situation where the variables are I(1) but not cointegrated, an ECM procedure cannot be pursued. A vector autoregressive (VAR) involving first difference of the variables is appropriate (see Salisu, 2015). We state as follows in equation (9), a $\rho^{\text {th }}$ order vector autoregression with exogenous variables $x$.

$$
y_{t}=C_{0}+A_{1} y_{t-1}+\ldots \ldots . .+A_{\rho} y_{t-\rho}+B_{0} x_{t}+B_{1} x_{t-1}+\ldots \ldots \ldots+B_{s} x_{t-s}+u_{t} \ldots .
$$

In equation (9), $C_{0}$ is as earlier defined just as $y_{t}$ and $x$. The notation $A_{1} \ldots \ldots . A_{\rho}$ stand for the coefficients of the autoregression involving lag one to $\rho$ while $B_{0} \ldots \ldots . . B_{S}$ denote the coefficients of the distributed lag from one to $s$.

\section{Findings}

The results in table 1 shows that the variables are integrated of order 1 . This means that we reject the assumption or null hypothesis of unit root or non-stationarity after first difference of the variables. In essence, the variables are stationary after first difference. This is for both consumption models with intercept or constant as well as with constant and linear trend. 
Table 1: Dickey Fuller (DF)-GLS Unit Root Test

\begin{tabular}{lllll}
\hline Variable & T-Statistics & $\mathbf{1 \%}$ & $\mathbf{5 \%}$ & Order of Integration \\
\hline $\begin{array}{l}\Delta \text { Private } \\
\text { Consumption }\end{array}$ & $-2.67^{* *}$ & -2.64 & -1.95 & $\mathrm{I}(1)$ \\
$\begin{array}{l}\Delta \text { Private } \\
\text { Consumption }\end{array}$ & $-3.23^{*}$ & -3.77 & -3.19 & \\
$\Delta$ Income $^{\mathrm{a}}$ & $-2.59^{*}$ & -2.64 & -1.95 & $\mathrm{I}(1)$ \\
$\Delta$ Income $^{\mathrm{b}}$ & $-6.92^{* *}$ & -3.77 & -3.19 & \\
\hline
\end{tabular}

Notes: a stands for constant model and ${ }^{\mathrm{b}}$ denotes constant and linear trend model. $\Delta$ indicates that the variables are in their first difference. The asymptotic critical values of Dickey Fuller GLS unit root tests are in their respective levels of significance. ${ }^{* *}\left({ }^{*}\right)$ signifies the rejection of the null hypothesis at $1 \%(5 \%)$ significance level. We approximated all the values to two decimal places.

Source: Authors' Computation

We conducted a first difference of the variables because they are not stationary at level. Running a regression involving the variables at level or raw state of the data will amount to obtaining a spurious or nonsense regression. This error is costly in regression analysis because spurious models are not desirable. Therefore, with the result that the variables become stationary after first difference, our estimated consumption model becomes desirable. The DF-GLS residual $(-1)$ for the constant model for consumption, constant and linear trend model for consumption, constant model for income and constant and linear trend model for income are all negatives which are $-0.78,-1.06,-0.63$ and -1.25 , in that order, which means that these models for which stationarity of each variable is based are viable. The study proceeds to test whether consumption and income have a cointegrating or long-run or equilibrium relationship using the Engle-Granger two stage approach. We presented the results in Table 2. There is no cointegration of the variables because the residual has a unit root. This is so because the t-statistic value of -2.13 in absolute term is less than the Engle-Granger critical value of -3.46 in absolute, for constant model at 5\% significance level (see Enders, 2012). Therefore, we cannot pursue an error correction mechanism.

Table 2: Engle and Granger Two-Stage Cointegration Test

\begin{tabular}{llll} 
& & & \\
& & t-Statistic & Prob.* \\
\hline Augmented Dickey-Fuller test statistic & -2.13 & 0.24 \\
Test critical values: & 1\% level & -3.68 & \\
& $5 \%$ level & -2.97 & \\
& $10 \%$ level & -2.62 & \\
\hline
\end{tabular}

*MacKinnon (1996) one-sided p-values.

Source: Authors' computation

The result of the Vector autoregression-in-first difference is in Table 3. The effect of first lag of income on consumption is correctly signed, though infinitesimal and insignificant. On the other hand, the effect of second lag of income on consumption is negative and a-theoretic but significant at $10 \%$ level. Immediate past year and last two years consumption exhibit significant impact on current consumption at $10 \%$ and $5 \%$, respectively. 


\begin{tabular}{l} 
Journal of Economics and Behavioral Studies (ISSN: 2220-6140) \\
Vol. 9, No. 5, pp. 219-229, October 2017 \\
\hline \hline
\end{tabular}

Table 3: Vector Autoregression-in-First Difference

\begin{tabular}{|c|c|c|c|c|}
\hline Variables & Coefficient & Std. Error & t-Statistic & Prob. \\
\hline$\overline{C(1)}$ & -0.342337 & 0.190960 & -1.792712 & 0.0793 \\
\hline $\mathrm{C}(2)$ & 0.393287 & 0.194158 & 2.025600 & 0.0484 \\
\hline $\mathrm{C}(3)$ & 0.000412 & 0.000442 & 0.932097 & 0.3560 \\
\hline$C(4)$ & -0.000770 & 0.000430 & -1.790108 & 0.0797 \\
\hline$C(5)$ & 9.644677 & 7.654333 & 1.260028 & 0.2138 \\
\hline$C(6)$ & 90.10232 & 86.92103 & 1.036600 & 0.3051 \\
\hline$C(7)$ & 24.94558 & 88.37671 & 0.282264 & 0.7790 \\
\hline $\mathrm{C}(8)$ & -0.007908 & 0.201002 & -0.039345 & 0.9688 \\
\hline$C(9)$ & 0.229187 & 0.195731 & 1.170929 & 0.2474 \\
\hline$C(10)$ & 2641.739 & 3484.091 & 0.758229 & 0.4520 \\
\hline \multicolumn{2}{|c|}{ Determinant residual covariance } & $2.81 \mathrm{E}+11$ & & \\
\hline \multicolumn{5}{|c|}{$\begin{array}{l}\text { Equation: COND1 }=\mathrm{C}(1) * \mathrm{COND} 1(-1)+\mathrm{C}(2) * \mathrm{COND} 1(-2)+\mathrm{C}(3) * \mathrm{YD} 1(-1)+ \\
\quad \mathrm{C}(4) * \mathrm{YD} 1(-2)+\mathrm{C}(5)\end{array}$} \\
\hline \multicolumn{5}{|c|}{ Observations: 29} \\
\hline R-squared & 0.562535 & \multicolumn{2}{|c|}{ Mean dependent var } & 8.484481 \\
\hline Adjusted R-squared & 0.489625 & \multicolumn{2}{|c|}{ S.D. dependent var } & 53.97695 \\
\hline S.E. of regression & 38.56143 & \multicolumn{2}{|c|}{ Sum squared resid } & 35687.62 \\
\hline Durbin-Watson stat & 1.853966 & & & \\
\hline \multicolumn{5}{|c|}{$\begin{array}{l}\text { Equation: YD1 = C }(6) * \text { COND1 }(-1)+C(7) * C 0 N D 1(-2)+C(8) * Y D 1(-1)+C(9) \\
* \text { YD1 }(-2)+C(10)\end{array}$} \\
\hline \multicolumn{5}{|l|}{ Observations: 29} \\
\hline R-squared & 0.143781 & \multicolumn{2}{|c|}{ Mean dependent var } & 4346.643 \\
\hline Adjusted R-squared & 0.001077 & \multicolumn{2}{|c|}{ S.D. dependent var } & 17561.81 \\
\hline S.E. of regression & 17552.35 & \multicolumn{2}{|c|}{ Sum squared resid } & $7.39 \mathrm{E}+09$ \\
\hline Durbin-Watson stat & 2.212408 & & & \\
\hline
\end{tabular}

Source: Authors' Computation

In order to test the joint significant of consumption at first and second lag as well as income at first and second lag on consumption, the Wald test is used. The results are, respectively, in Tables 4 and 5 . The Chisquare p-value of zero in Table 4 shows that the past consumption levels are significant in explaining consumption levels in Nigeria at $1 \%$ and $5 \%$ levels.

Table 4: Wald Test on Joint Significance of Consumption Lags on Current Consumption

\section{System: \%system}

\begin{tabular}{llll} 
Test Statistic & Value & Df & Probability \\
\hline Chi-square & 21.97447 & 2 & 0.0000
\end{tabular}

Null Hypothesis: $c(1)=c(2)=0$

Null Hypothesis Summary:

Normalized Restriction ( $=0$ )

Value

Std. Err.
$\mathrm{C}(1)$
$-0.342337$
0.190960
$\mathrm{C}(2)$
0.393287
0.194158

Restrictions are linear in coefficients.

Source: Authors' Computation

Table 5 reveals that income at first and second lags are not jointly significant in explaining the changes in the consumption level in Nigeria. This means that other factors other than income may be pertinent in determining what majorly influence people's consumption in the country. This finding is contrary to the 
results many empirical studies in the past that recognize the potent role of the influence of income in determining consumption (see Keynes, 1936; Chamberlin and Yueh, 2006; Parker, 2010; Amin, 2015). One explanation to our result is that the culture of interdependence remains strong in Nigeria. The income of an individual can be shared with those of have-nots in his family. As a result, his income may not strongly determine his consumption level.

Table 5: Wald Test on Joint Significance of Income Lags on Current Consumption

\section{System: \%system}

\begin{tabular}{llcc} 
Test Statistic & Value & Df & Probability \\
\hline Chi-square & 4.249563 & 2 & 0.1195
\end{tabular}

Null Hypothesis: $\mathrm{C}(3)=\mathrm{C}(4)=0$

Null Hypothesis Summary:

Normalized Restriction $(=0)$

$\mathrm{C}(4)$

$\begin{array}{ll}\text { Value } & \text { Std. Err. } \\ 0.000412 & 0.000442 \\ -0.000770 & 0.000430\end{array}$

Restrictions are linear in coefficients.

Source: Authors' Computation

\section{Conclusion}

This study gave a synthesis on the major theroretical and empirical issues on consumption as relates to its meaning, funtion, theories and determinants. Starting from the Absoulte Income Hypothesis (AIH) propounded by the father of macroeconomics, Maynard Keynes in 1936 to David Laibson's Pull of Instant Gratifification Hypothesis (PIGH) published in 1997 and the latest edition published in 2013 in conjunction with Christopher Harris, consumption function remains a multivariate concept. Therefore, macroeconomists are faced with the problem of which variable to select when analyzing factors determining consumption. There are also econometric challenges as to how effective and reliable to measure some of the theoretical variables like permanent income, permanent consumption, transitory income, transitory consumption, rational expectation and psychological factors. However, econometricians have made much success than failure on the problem. Due to the fact that the AIH and Relative Income Hypothesis (RIH) are not forward looking about how to smooth consumption and the fact that interdependent utility function suggested by the RIHhas methodological problem, both hypotheses have been abandoned. Nevertheless, any consumption function build-up even up to the contemporay time often takes its root from the AIH where disposable income is a foundational determinant of consumption. Our test of the general consumption function shows that income's effect on consumption in Nigeria may be negligible and its two lags combined may be insignificant. Rather, previous consumption may be significant in influencing current consumption in the country. By implication, this may suggest that Nigerian government would be expected at any time to gauge its present economic indices(for example, changing components of the aggregate demand) with those of previous years than putting blame on previous governments. This is because consumption is the largest component of aggregate demand in Nigeria. There is nothing new about government actions, for instance in the area of debt accumulation, being strategic and trying to play a ponzi game with the masses. What is important for every government is to deliever on its election promises.

One implication of the PIH and LCH is that people do not respond to policy favourably when they know that the changes in the policy is temporary. For instance, if a government fixes income tax surcharge to say 10 percent because of high inflation in the economy so as to reduce aggregate demand as a temporary measure, people may use part of their savings to maintain their previous consumption or reduce it slightly. Experiences have shown that consumption only falls a little and inflation either increases or remains unchanged or 
reduces slightly. This means that government would have overestimated the expected deflation from the tax policy. Permanent policies have more impacts on the economy than the temporary ones. It suffices that government must indicate whether its policy is permanent and where it is temporary and not harsh, government may choose to be silent. Where the policy is very harsh and temporary, it will be better if government choose not to be silent. However, the fact remains that government cannot fool all its citizens through its policies. Governments must always be credible with its policies to raise the belief of the public thereby making itspolicies more effective. This study has reinforced the abandonement of the PIH on the ground of weak explanatory power of income in explaining consumption. Since the extent of private consumption in a country can throw some lights on welfare of a citizen, it can be suggested that increase in a country's income as well as those of its citizens are not the altimate for gauging welfare.

\section{References}

Amin, B. (2015). Test of Keynesian Consumption Function: A Case Study of University of Punjab. Management and Administrative Sciences Review, 4(5), 787-800.

Ando, A. \& Modigliani, F. (1963). The Life-Cycle Hypothesis of Saving: Aggregate Implications and Tests. American Economic Review, 53, 55-84.

Blanchard, O. \& Fischer, S. (1989). Lectures on Macroeconomics. MIT Press.

Central Bank of Nigeria. (2014). Statistical Bulletin (Volume 25). Abuja: Statistics Department

Chamberlin, G. \&Yueh, L. (2006). Macroeconomics. London: Thomson Learning.

Diamond, P. A. (1965). National Debt in a Neoclassical Growth Model. American Economic Review, 55, 11261150.

Duesenberry, J. (1949). Income, Saving and the Theory of Consumption Behavior. Cambridge, Mass: Harvard University Press.

Enders, W. (2012). Applied Econometric Time Series (3 ${ }^{\text {rd }}$ ed.).New Jersey: Wiley.

Engle, F. \& Granger, C. W. J. (1987). Co-integration and Error Correction: Representation, estimation and testing. Econometrica, 55(2), 251-276.

Elliott, G., Rothenberg, T. J. \& Stock, J. H. (1996). Efficient Tests for an Autoregressive Unit Root. Econometrica, 64, 813-836.

Fisher, I. (1930). The Theory of Interest. New York, NY: Macmillan.

Friedman, M. (1957). A Theory of the Consumption Function. Princeton University Press.

Hall, R. E. (1978). Stochastic Implications of the Life Cycle- Permanent Income Hypothesis: Theory and evidence. Journal of Political Economy, 86(6), 971-987.

Harris, C. \& Laibson, D. (2013). Instantaneous Gratification. Quarterly Journal of Economics, 128(1), 205-248.

Keynes, J. M. (1936). The General Theory of Employment, Interest and Money. New York, NY: Harcourt, Brace.

Kuznets, S. (1942). Uses of National Income in Peace and War. Occasional Paper 6. New York, NY: National Bureau of Economic Research.

Laibson, D. (1997). Golden Eggs and Hyperbolic Discounting. Quarterly Journal of Economics, 62(2), 443-478.

Ng, S. \& Perron, P. (2001). Lag Length Selection and the Construction of Unit Tests with Good Size and Power. Econometrica, 69, 1519-1554.

Romer, D. (2011). Advanced Macroeconomics (4th ed.). New York, NY: McGraw: Hill.

Salisu, A. (2015). Multivariate Models. Centre for Econometric and Allied Research Workshop, Module IV, Ibadan.

Modigliani, F. \& Brumberg, R. (1954). Utility Analysis and the Consumption Function: An Interpretation of Cross-section: An Interpretation of Cross-section Data. In K. Kurihara (Eds.), Post-Keynesian Economics. New Brunswick, NJ: Rutgers University Press.

Parker, J. (2010). Theories of Consumption and Saving. Economics 314 Coursebook.

Weil, P. (2008). Overlapping Generations: The First Jubilee. Journal of Economic Perspectives, 22(4), 115-34. 